\title{
A Comparative Analysis on Subsidy Policies of China's Public Housing Programmes: Evidence Based on Micro Surveys in Baoji
}

\author{
Nannan Yuan
}

\author{
Graduate School of Economics, Kobe University, Japan
}

\begin{abstract}
To understand the effects of the public housing programme and measure the feasibility of subsidy policies, this study conducts a comparative analysis on the wealth effects of two of the main subsidy policies which are the selloriented policy ${ }^{1}$ (SOP) and rent-oriented policy ${ }^{2}$ (ROP), implemented in the city of Baoji, China. The data in this study come from a survey conducted in 2010 in Baoji. We apply a Cobb-Douglas utility function to measure the extra benefits for households that fall under the SOP and households that fall under the ROP. Our results indicate that the low-income SOP households have a stronger taste in terms of housing consumption, and although both policies offer benefits to households, ROP households benefit more than SOP households do. The main policy conclusions drawn from our findings are that the ROP should be adopted first, and restricting resale by the purchasers is the key to achieve policy efficiency.
\end{abstract}

Keywords: Public housing, Sell-oriented policy, Rent-oriented policy.

\section{INTRODUCTION}

The Chinese Ministry has acknowledged that the main housing problem in China is unaffordability of urban poverty (Deng et al. 2009). Increasing concerning about urban poverty and its influence on economic prosperity and social stability, the Chinese government has developed the public housing ${ }^{3}$ programme, which had its official origin in Ways to Provide Public Housings for the Poorest Urban Residents in 2004, the goal of which is strengthening the public housing programme. Via the public housing programme, the government provides housing or housing subsidies to low-income households to help them improve their housing conditions or to obtain houses in which to live (Xie 2011). Until 2006, few local governments had officially used the programme, but by 2010, almost all local governments in China had constructed public housing units.

When a public housing programme is implemented, the subsidy method is one of the most important

*Address correspondence to this author at the Graduate School of Economics, Kobe University, 2-1 Rokkodai-cho, Nada-ku, Kobe, 657-8501, Japan; Tel: +8108043989693; E-mail: wsyuanan@hotmail.com

JEL Classification: H53, I38, R28.

${ }^{1}$ Sell-oriented policy (SOP) is a policy that local governments sell public houses to low-income households to obtain the funding when implementing the public housing programme.

${ }^{2}$ Rent-oriented policy (ROP) is a policy that low-income households rent public houses conducted by the governments.

${ }^{3}$ Public housing is usually called 'low-rent housing' in China, but is similar to public housing in other countries. In the whole country, public housing is managed by Ministry of Housing and Urban-Rural Development of the People's Republic of China (MOHURD). In local, it is managed by local governments' Housing Security Centres. In this paper, we use the term 'public housing' for the purpose of comparison and understandability. aspects (Gilbert 2012). According to the public housing programme laws, there are two main public housing subsidy policies: a rent-oriented policy (ROP) and a rent subsidy policy ${ }^{4}$. Housing subsidies have been able to solve the housing problem effectively in Chile, Colombia, and South Africa, but only by having adequate funding (Gilbert 2004). Besides, when central government urged local governments to establish the public housing programme, it did not dedicate funding for this purpose (Deng et al. 2009). Although some funding was provided by the central government, it was often very limited and not guaranteed (Deng et al. 2009). Hence, local governments were responsible for carrying out the construction programmes ${ }^{5}$. Therefore, to obtain the funding they needed, some local governments began selling public houses, which they had constructed, to low-income households at a very low price. In this way, local governments were able to ensure there were sufficient funds for the construction assignments being implemented in the next period. In this study, we refer to this method of subsidising lowincome housing as a 'sell-oriented policy (SOP)'.

Thus, public housing constructed by local governments is subject to two main subsidy policies:

\footnotetext{
${ }^{4}$ When implementing the ROP, low-income households rent public housing constructed by the governments. The rent subsidy policy enables a government to give rent subsidies to low-income households to help them to rent housing in the normal rental market.

${ }^{5}$ Funding for these housing units came from various sources. The central government provided about $33.33 \%$ of the funds, and the provincial government provided about $16.67 \%$ of the funds. The remaining $50 \%$ came from the local government itself. In China, governments can be classified into five main administrative levels: the first level is the central government, which sits above the other four; second is the provincial government; third is the city government; fourth is the county government; and the fifth level is the township government. A higher level of government can overrule lower ones, to a certain extent. Public housing projects are typically constructed by a city government. Therefore, in this paper, 'local government' refers to a city government.
} 
the SOP and ROP. However, there are no rules or laws governing the SOP public housing programmes. Several officials from local governments, such as those in Baoji city, believe that the SOP helps governments to recycle construction funds rapidly, and so are in favour of it. On the other hand, some officials at the central government level insist that, in the case of a public housing shortage, the policy is counter to the goal of helping as many low-income households to obtain housing. Their reasoning is that, if public housing is sold to low-income households, those houses exit the market immediately, and can no longer be used for renting, so should take the ROP. The debates between SOP and ROP make it crucial to discuss their wealth effects on low-income households.

To the best of our knowledge, little studies in China have investigated the wealth effects of SOP and ROP on low-income households in public housing programmes. Especially, it is worth comparing the effects of the SOP and ROP in China. To do this, applying Cobb-Douglas utility function, this paper calculates the wealth effects of SOP and ROP on lowincome households by using survey data conducted in Baoji city in China. The results indicate that although both the SOP and ROP offer benefits to low-income households, ROP households benefit more than SOP households do. The rest of this paper is organized as follows. Section 2 reviews existing literatures. Section 3 outlines the Cobb-Douglas utility function and suggests possible extra benefits. Section 4 describes our data and summarizes households' characteristics. Section 5 discusses our empirical results on the extra benefits to each household group. Then, Section 6 concludes the paper by summarizing our main findings.

\section{LITERATURE REVIEW ${ }^{6}$}

When it comes to public housing programmes, rent subsidies are widely adopted around the world. Rent subsidies and public housing programmes have a social benefit, but also contain both economic effects and welfare effects for the society (Tiwari and Hasegawa 2001; Koning and Ridder 1997). In particular, low-income households receive more benefits. However, one difficulty with these subsidies is how to calculate the benefits distribution between different kinds of low-income households. Kraft and

${ }^{6}$ In fact, much of the references are very dated in this paper. Because many countries have been implementing the public housing program for many years, e.g., US begun it in 1930s, Hong Kong is 1953, British is 1920s, the researchers study the related problems are dated (China begun it in 2006).
Olsen (1977) measured the distribution of direct benefits to different households by using a general equilibrium model. They found that the mean benefits first rise and then fall, depending on the household income; for households with the lowest income levels, there are almost no benefits. Another study by Murray (1975) indicated that the distribution of consumers' surplus depends mainly on individuals' characteristics, such as level of income, the age of the head of the household, race, and family composition. This study used a Cobb-Douglas utility function and a Constant Elasticity of Substitution (CES) utility function to analyse the effects on different households. Even though there was not much difference in average benefits, the results showed that, in the Cobb-Douglas case, the coefficients of non-housing goods and the age of the head of the household are positive and significant, while the coefficient of income is positive, but not significant. Wong and Liu (1988), using a CobbDouglas utility function, found that the public housing programme is inefficient in Hong Kong, because poor public housing tenants obtain more benefits than the rich, and because many of the poor are not covered by the public housing programme.

In our case, the sell-oriented policy is similar with the privatisation of public housing, which is a residential sale programme for those public and eligible private rental housing tenants. This policy was launched in 1978 in Hong Kong - Home Ownership Scheme (Ho 2004); and in US the launch of the privatisation of public housing ${ }^{7}$ was in 1988 (Schill 1990). Some studies suggested that privatisation of public housing would be an alternative policy for public housing programme. Ho (1995) pointed out that in Hong Kong, privatisation of public housing is economic efficiency, 'policy efficiency', and equity. In further, Ho (2004) discussed methods of privatisation of public housing, and examined the privatisation process by applying the sequential model. The results indicated that the government should not ignore numerous mistakes in the privatisation process, and do something to replace market interventions with market mechanisms. According to Kirwan (1984), privatisation is a component of a general trend towards reconstructing public and economic rental housing markets. However, during this strategy, the filtering effect of the policy results in the least advantaged household living in the

\footnotetext{
${ }^{7}$ The Commission on Privatization recommended that Congress direct the United States Department of Housing and Urban Development ('HUD') to sell public housing units to tenants at discounted prices (Schill 1990).
} 
worst accommodation and unwilling to pay increased rents (Flynn 1988). Hence, Schill (1990) pointed out that privatization of public housing remains at the forefront of housing policy debates.

Research on the public housing programme in China is still characterised by controversy on which kind of subsidy policy should be adopted. Several researchers point out that, when there is a shortage of housing stock, the ROP should be chosen (Jiang 2007; Liu 2004). Zhang (2009) suggested that, in the short term, the ROP is more efficient. Then, in the long term, this policy should transition to a rent subsidy policy. The effects of the public housing subsidy policy were analysed by Zhou (2008, 2010). Zhou (2008) compared households receiving rent subsidies to those who are not subsidized, and found that there are some problems, for example, in Shanghai, there is a level of inequity and insufficiency when the rent subsidy policy is used. In further, Zhou (2010) established a logistic model to analyse the factors that influence the policy effects. The results showed that household size, location, and people's willingness to purchase in future seem to influence the policy effects.

\section{UTILITY FUNCTION AND BENEFITS}

This study assumes there are only two kinds of goods in the market: a housing service and nonhousing goods. The market is assumed to be perfectly competitive and in equilibrium in the long run. This means that in the long run, the supply curves of the two goods are perfectly elastic. Housing services are measured by several attributes, including floor area, number of bedrooms, whether the house has a bathroom, and orientation.

The prices of housing services and non-housing goods are $P_{H}$ and $P_{C}$, respectively. Under the public housing programme, a family is offered ' $H$ ' units of housing services. Households under the SOP have to pay $H \cdot P_{H}^{s}$ to buy a public housing unit, and consume $C_{b}$ units of non-housing goods by using their surplus income. Similarly, families under the ROP need to pay a rent of $H \cdot P_{H}^{r}$ to rent the public housing unit, and consume $C_{r}$ units of non-housing goods using their surplus income. Since these are public housing units, the prices, $P_{H}^{s}$, and rents, $P_{H}^{r}$, are lower than in commercial housing units in the open market. Therefore, participants in the public housing programme obtain benefits and welfare from this programme. Do households under the SOP and ROP obtain the same benefits and welfare? If not, which of the two obtains more? To answer these questions, assessing these benefits is necessary.

The benefits to eligible households in public housing programmes are equivalent to receiving an unrestricted cash grant, $B$. For households under the SOP, this is $B_{s}$; for households under the ROP, this is $B_{r}$. Here, $B$ refers to the difference between the market value and the real expenditure on the goods consumed by households under the public housing programme. To calculate the value of the cash grants, $B$, this study adopt the Cobb-Douglas utility function ${ }^{8}$ to estimate households' benefits.

A simple form of this function is as follows:

$U=H^{\alpha} C^{1-\alpha}$

where $U$ is a household's utility; $H$ refers to the consumption of housing services; $C$ represents the consumption of non-housing goods. In addition, $\alpha^{9}$ is the proportion of income spent on housing by a consumer facing the following budget constraint:

$H \cdot P_{H}+C \cdot P_{C} \leq Y$

where the variables are defined as they were before the consumer became part of the housing programme. Subject to the budget constraint (2), the consumer will maximize his or her utility. We solve the utility maximization problem for the consumer by using a Lagrangian function. The optimal solutions are as follows:

$H=\alpha Y / P_{H}$ and $C=(1-\alpha) Y / P_{C}$

In addition, by the first-order condition, optimal solutions need to satisfy the condition:

\footnotetext{
${ }^{8}$ Similar previous studies have mainly used three utility functions: the CobbDouglas utility function (Kraft and Olsen 1977; Murray 1975; Wong and Liu 1988.), the Constant Elasticity of Substitution (CES) utility function (Murray 1975), and the Stone-Geary utility function (Johnson and Hurter 2000). Murray (1975) compared the parameters of the generalized CES and Cobb-Douglas utility functions when estimating the distribution of benefits in public housing programmes. The author suggested that the Cobb-Douglas utility function may be useful for computing aggregate benefits. One of our important objectives is to compute the aggregate benefits of subsidized low-income households. In addition, Murray (1975) pointed out that the CES utility function would be the better option when studying structural characteristics, such as the correlation between income or age and the benefits. In our case, households are eligible if they have special certifications, such as the 'Certification of Minimum Subsistence Security for the Urban Residence', 'Certification of Five Guarantees Family', and the 'Certification of Disabled People'. This means that the policy does not depend only on income or age. The Stone-Geary utility function could be used to solve problems that involve subsistence levels of consumption (Johnson and Hurter 2000). In our case, the households are the lowest income households, which means all consumption of housing services and non-housing goods are at or below subsistence levels. Hence, the CobbDouglas utility function is the most appropriate for our study.

${ }^{9}$ Here, $\alpha$ also represents the consumer's preference for housing. A higher value means a stronger taste for housing consumption.
} 


$$
H \cdot P_{H}+C \cdot P_{C}=Y
$$

This implies that the income of the consumer is used completely. Here, $H \cdot P_{H}$ is the housing expenditure. Therefore, the consumption of nonhousing goods (all non-housing goods being represented here by a composite commodity) is

$C=Y-H \cdot P_{H} / P_{C}$

Next, we suppose that the consumer participates in the public housing programme. Then, with an income of $Y_{1}$, the consumer obtains $H_{1}$ housing units and $C_{1}$ units of non-housing goods. He or she may obtain these under either the SOP or ROP. The two options do not affect the analysis. Then, the utility level of the consumer is

$U_{1}=H_{1}^{\alpha} C_{1}^{1-\alpha}$

Suppose the consumer's taste in housing does not change. This means the value of $\alpha$ remains constant while the consumer participates in the public housing programme. To obtain $U_{1}$ in the open market, how much income is necessary for the consumer?

For a given income, $Y_{1}$, the consumer participating in the public housing programme would consume the following quantity of non-housing goods:

$C_{1}=Y_{1}-H_{1} \cdot P_{H_{1}} / P_{C}$

In this case, $P_{C}$ is constant because, in the short term, the market price of non-housing goods does not change. By minimizing $H \cdot P_{H}+C \cdot P_{C}$, subject to $U_{1}=H_{1}^{\alpha} C_{1}^{1-\alpha}$, to obtain $U_{1}$ in the open market, the necessary income is

$Y_{1}^{\prime}=\left(H_{1} \cdot P_{H}^{e} / a\right)^{a}\left\{\left(Y_{1}-H_{1} \cdot P_{H_{H}}\right) /(1-a)\right\}^{(1-a)}$

where $P_{H}^{e}$ is the market price of the housing service, which is not affected by the public housing programme. In our case, $P_{H}^{e}$ contains the market selling price, $P_{H}^{e s}$, for the SOP and the market rent price, $P_{H}^{e r}$, for the ROP. In addition, $\left(Y_{1}^{\prime}-Y_{1}\right)$ is the benefit the consumer obtains from the public housing programme. Hence, the total benefit value for the consumer participating in the public housing programme is given by:

$$
B=Y_{1}^{\prime}-Y_{1}
$$

Substituting the average values into equation (9) could obtain the average benefits. To compare the benefits obtained by households under the SOP and ROP, it is needed to calculate $B_{s}$ for SOP and $B_{r}$ for ROP, respectively. If $B_{s}>B_{r}$, the benefits obtained by the households under the SOP are higher, and SOP is more effective. Otherwise, ROP is more effective.

To obtain the average benefits, it is needed to calculate the value of $\alpha$ first. In the short term, this study supposes that the consumer's preference does not change, which means $\alpha$ remains constant before and after participation in the public housing programme. Thus, $\alpha$ could be calculated from the values of $H \cdot P_{H}$ and $Y$ from before the consumer participated in the public housing programme. The value of $\alpha$ is the proportion of income spent on housing by a consumer. Hence,

$\alpha=\left(H \cdot P_{H}\right) / Y$

\section{DATA}

This empirical study is based on cross-sectional data originating from a survey conducted in the city of Baoji in July 2010. Baoji is one of the biggest cities in northwest China, and began constructing public housing in $2006^{10}$. By the end of 2010, the local government of Baoji had constructed 4110 public housing dwellings, with a combined building area of 205500 square metres. The main public housing areas were the XFY area, the CSL area, and the LFY area. By September, 2010, 1361 households lived in the public housing dwellings in these areas, and $72.30 \%$ of which was in XFY area. Hence, according to random cluster sampling method, we did investigation in XFY area, where we successfully interviewed 75 households. Although our sample size is rather small ${ }^{11}$, it will not affect our analysis. On the one hand, when Kraft and Olsen (1977) estimated the relationship between the rent-income ratio and family characteristics, they used 168 observations. They divided these observations into four groups. Three groups contained 40 observations, with the remaining group containing 48 observations. However, the small number of observations did not affect their analysis. On

\footnotetext{
${ }^{10}$ In China, the year of 2006 is when public housing officially began to be constructed.

${ }^{11}$ We have tried to enlarge our sample and did this investigation again in 2012 Because there are no rules or laws governing the sell-oriented policy, local government of Baoji city was criticized in 2012. Most households were not willing to be interviewed for fear of criticism or punishment. Hence, we were not able to achieve a bigger sample size.
} 
Table 1: Summary Characteristics by Type of Subsidy

\begin{tabular}{|c|c|c|c|}
\hline Variables & All & Households in SOP & Households in ROP \\
\hline Number of households & 75 & 63 & 12 \\
\hline Age of head of household & 51.55 & 52.03 & 49 \\
\hline Proportion of age $18-30(\%)$ & 2.67 & 1.59 & 8.33 \\
\hline Proportion of age $31-45(\%)$ & 34.67 & 39.68 & 8.33 \\
\hline Proportion of age $46-60(\%)$ & 45.33 & 39.68 & 75 \\
\hline Proportion of age over $60(\%)$ & 17.33 & 19.05 & 8.33 \\
\hline Years of schooling of head of household & 9.53 & 9.34 & 10.5 \\
\hline Household size & 3.11 & 3 & 3.75 \\
\hline Number of Children & 41 & 37 & 4 \\
\hline Proportion of age $0-9(\%)$ & 24.4 & 24.32 & 25 \\
\hline Proportion of age $10-18(\%)$ & 75.60 & 75.68 & 75.00 \\
\hline
\end{tabular}

Source: Summarized by the author from the survey conducted in Baoji in 2010.

the other hand, to some extent, our sample could represent some characteristics of the whole population. First, the proportion of households under the SOP of our sample is close to the proportion of Baoji's overall figure. By September 2010, 1361 dwellings were in use. Of these, 1148 dwelling units had been bought. Thus, the proportion of low-income households under the SOP was about $84.35 \%$. In our sample, of the 75 low-income households, 63 bought public housing units under the SOP, and the proportion of households under the SOP is $84 \%$. Second, the status of lowincome households in our sample is similar to that of the whole population. In Baoji city, the annual disposable income of these households under public housing programme is no more than $15000 \mathrm{RMB}$, and per capita living space of these households is no more than 14 square metres. From Table 2, we see the similar status of our sample. Third, the public housing dwellings constructed in different areas have similar standards. Floor spaces of one public housing dwelling are about 60-70 square metres with the type of one sitting-room, two bedrooms and one bathroom. Also, the distances of public housing dwellings from city centre are about 3.5 kilometres.

Our survey data includes detailed information on each house characteristic, including the housing area, expenditure on housing services, the living conditions, and the distance from the city centre. For all households $^{12}$, data on annual disposable income ${ }^{13}$, as

\footnotetext{
${ }^{12} \mathrm{~A}$ household in this study refers to a family, including all family members who are in the same Residence Registration Booklet, which is a certification that a person belongs to a family in an administrative region.
}

well as other important household characteristics, such as the household size, number of children, age and years of schooling of the head of the household, were also collected. The survey collected data on the household before and after moving into the public housing. Table 1 summarizes the characteristics of surveyed households.

Local governments have flexibility in determining who is eligible and what types of units should be provided (Deng et al. 2009). According to the laws of the public housing programme, eligible households need to hold a special certification, such as the 'Certification of Minimum Subsistence Security for the Urban Residence', 'Certification of Five Guarantees Family', and the 'Certification of Disabled People'. These all certify that a person is eligible to be subsidized by the public housing programme. In our sample, $89.33 \%$ of the households hold these certifications. Table 1 shows that the average education level of a head of a household is only 9.53 years of schooling. Besides, only $9.3 \%$ of the heads of households in our sample had received college education. The low average education level makes it more difficult for a household to find work as technology develops. In addition, the heads of the households with the average age of 51.55 are mostly the workers who were laid off during the reformation of the state enterprises. Those households are easier to obtain special certifications, as well as the disabled people. Another criterion used to judge eligibility is

\footnotetext{
${ }^{13}$ Annual disposable income refers to the amount of money that households
} have available to spend and save after deducting income tax. 
Table 2: Characteristics of Households Surveyed in Baoji

\begin{tabular}{|c|c|c|c|c|c|c|}
\hline Variables (unit) & \multicolumn{3}{|c|}{ SOP } & \multicolumn{3}{|c|}{ ROP } \\
\hline Annual disposable income (RMB) & 12097.01 & 14122.78 & 2025.77 & 13951.13 & 15858.50 & 1907.37 \\
\hline $\begin{array}{c}\text { Average expenditure for housing service per } \\
\text { area per year (RMB) }\end{array}$ & 90.72 & 15.72 & -75.00 & 50.64 & 14.64 & -36.00 \\
\hline $\begin{array}{l}\text { Highest expenditure for housing service per } \\
\text { area per year (RMB) }\end{array}$ & 240.00 & 18.72 & -221.28 & 60.00 & 27.60 & -32.40 \\
\hline $\begin{array}{l}\text { Average expenditure for non-housing goods } \\
\qquad \text { (RMB) }\end{array}$ & 8373.04 & 10871.29 & 2498.25 & 6542.66 & 14081.62 & 7538.96 \\
\hline Housing area per capita $\left(\mathrm{m}^{2}\right)$ & 11.93 & 23.18 & 11.25 & 5.99 & 12.21 & 6.22 \\
\hline Highest value of housing area per capita $\left(\mathrm{m}^{2}\right)$ & 40.00 & $37.62 *$ & -2.38 & 8.10 & 22.00 & 13.90 \\
\hline Without kitchen and bathroom (\%) & 52.38 & 0.00 & -52.38 & 75.00 & 0.00 & -75.00 \\
\hline
\end{tabular}

Source: Summarized by the author from the data of a survey conducted in Baoji city in 2010.

Notes:

1. For the SOP, after buying public housing, the expenditure for housing services per area per year is calculated by purchase price, housing area, and usage year. Housing expenditure per area per year equals to purchase price divided by the multiplier of housing area and usage year. In China, the legal limit for the usage year of residential land is 70 years, and as such, here, the usage year is set as 70 .

2. ${ }^{*}$ Here, the highest value of housing area per capita has decreased. The main reason is that the housing area per capita is calculated by dividing the overall housing area by the total population. In the actual calculation, total population means the census register population, which changed in the time before and after buying public housing. For example, the household with the highest housing area per capita before buying public housing contains one census register population. However, there are actually four people living in the house. Their housing area is 40 square metres. Then, by the function and policy standard, the housing area per capita is 40 . However, after buying public housing, the census register population of the household would have changed to 4 , with a housing area of 74 square metres. Therefore, the value of housing area per capita would have changed to 37.62 .

annual disposable income. The annual disposable income per capita for urban households in Baoji was $13225 \mathrm{RMB}^{14}$ in 2008 and $16346 \mathrm{RMB}$ in $2009^{15}$. In contrast, this value for the households in our survey was 4089.84 RMB in 2008 and 4562.84 RMB in 2009, or $30.93 \%$ and $27.91 \%$ of the urban average, respectively. Therefore, the disposable income of subsidized households is lower than that of the average urban household.

Households who satisfy the above criteria have priority when it comes to receiving a subsidized dwelling unit. In our sample, the local government provides dwelling units to low-income households in two ways: SOP and ROP. Table 2 compares the characteristics of households under the SOP and ROP, as well as the differences before and after the implementation of the policies.

From Table 2, the annual disposable income of those who choose to buy public housing is lower than those who choose to rent them. The reasons why there

\footnotetext{
${ }^{14} \mathrm{RMB}$ is the monetary unit of China.

${ }^{15}$ The data come from 'Shanxi Statistical Yearbook in 2009'.
}

are more households preferring to buy public housing are as follows. First, the prices of public housing units are lower than the prices of commodity housing, although they provide similar conditions. The average price of public housing units is $1100.4 \mathrm{RMB}^{16}$ per square metre. However, the average market price for commodity houses is $2711.3 \mathrm{RMB}^{17}$ per square metre, which is as 2.46 times greater than that of public housing units. Second, the prices of public housing units are lower than their costs. In 2006, the average costs of public housing units were 1180 RMB per square metre in Baoji. The prices had increased to 1500 RMB per square metre by 2010. In our sample, the low-income households bought the public housing units after 2007, when the price was 1100.4 RMB per square metre. The fact that prices are lower than costs encourages low-income households to buy public housing units. Third, in the traditional view, households favour buying public housing units. According to the survey, owning the fixed usage rights of public housing

\footnotetext{
${ }^{16}$ This information comes from the survey conducted in Baoji.

${ }^{17}$ This information comes from the China Premium Database in the CEIC Database, a database of comparative economic data for over 120 countries.
} 
units brings more happiness and sureness to the households. The fixed usage rights indicate that they do not need to move frequently and could live in the houses for 70 years. Hence, most low-income households want to buy public housing units. Fourth, low-income households could borrow money without interest from relatives. Although most of the lowincome households could not afford houses by themselves, with the funds borrowed from relatives, they were able to do so. In the survey, there is no interest when households borrow money from their relatives, which encourages low-income households to borrow money and buy public housing units.

After participating in the public housing programme, the annual disposable income of households under both the SOP and ROP increased, although the figures for the SOP households showed a greater increase. Most of the households who buy public housing units have to return the borrowed money. They might do many types of work to earn enough to do so. Besides, expenses for non-housing goods increased for all households after participating in the public housing programme. This is partly because of the increase in annual disposable income, but also because the housing expenses decreased.

\section{EMPIRICAL RESULTS}

\subsection{Estimating $\alpha$}

To obtain the benefits, $B$, for households participating in the public housing programme, this study first use equation (10) and the average household data before participating in the public housing programme to calculate $\alpha$.

For households under the SOP, before participating in the public housing programme, the average housing area per capita is 11.93 square metres. In addition, Table 1 shows us the average household size is three persons. Therefore, the average housing area per household is 35.79 square metres ${ }^{18}\left(H^{s}\right)$. The average price of a house is $90.72 \mathrm{RMB}$ per square metre $\left(P_{H}^{s}\right)$. Hence, the average expenditure on housing services is $3246.8688 \mathrm{RMB}$. The average value of the annual disposable income is $12097.01^{19} \mathrm{RMB}\left(Y^{s}\right)$. Therefore:

\footnotetext{
${ }^{18}$ This paper uses the housing area as a proxy for the consumption of housing services.

${ }^{19}$ Actually, the expenditure on non-housing goods (shown in Table 2) is 8373.04 RMB. The total expenditure for housing services and non-housing goods is equal to $11619.9088 \mathrm{RMB}$. The difference between total expenditure and annual disposable income is savings.
}

$\alpha_{s}=H^{s} \cdot P_{H}^{s} / Y^{s}=35.79 \times 90.72 / 12097.01=0.2684$

In the same way, for households under the ROP, the average housing area per capita is 5.99 square metres. Table 1 shows that the average household size under the ROP is 3.75 persons. Hence, the average housing area per household is 22.4625 square metres $\left(H^{r}\right)$. The average rent is $50.64 \mathrm{RMB}$ per square metre $\left(P_{H}^{r}\right)$. Hence, the average housing expenditure is 1137.5010 RMB. The annual disposable income of households under the ROP is $13951.13 \mathrm{RMB}\left(Y^{r}\right)$. Therefore,

$\alpha_{r}=H^{r} \cdot P_{H}^{r} / Y^{r}=22.4625 \times 50.64 / 13951.13=0.0815$

From the above values, $\alpha_{s}>\alpha_{r}$, which reveals that households under the SOP have a stronger taste in housing than households under the ROP. A lowincome household who values houses would most likely buy a public house. We can now derive the utility functions for households under the SOP and ROP, as follows:

For households under the SOP, the utility function is

$U_{s}=H^{0.2648} C^{0.7316}$

For households under the ROP, the utility function is

$U_{r}=H^{0.0815} C^{0.9185}$

Because the sample is selected from one city, the two functions only represent the utilities of low-income households in Baoji who participated in the public housing programme. Although our sample size was small, this could still illustrate some problems with the programme. Using the utility functions, this study then calculates the profits/benefits for households under the SOP and ROP.

\subsection{Comparison of Benefits}

Based on Equations (8) and (9), the benefits could be obtained from the public housing programme. First, this study applies Equation (8) to calculate the necessary income for the households after participating in the public housing programme. For households under the SOP, after buying public housing units, the per capita housing area is 23.18 square metres. This study assumes that household size is constant before and after participating in the public housing programme. Hence, the average household size is three persons, and per household housing area is 69.54 square metres $\left(H_{s 1}\right)$. The market price of commercial residential housing per square metre was 
2711.3 RMB in Baoji in 2009. Since the usage years for commercial residential housing is limited to 70 years, the housing price per year per square metre is 38.7 RMB $\left(P_{H}^{e s}\right)$. However, the selling price of public housing units per year per square metre is $15.72 \operatorname{RMB}\left(P_{H_{1}}^{s}\right)$, as shown in Table 2. After moving into public housing units, the annual disposable income, $Y_{s 1}$, is 14122.78 RMB (see Table 2). Based on Equation (8), necessary income for households under the SOP is as follows.

$$
\begin{aligned}
& Y_{s 1}^{\prime}=(69.54 \times 38.7 / 0.2684)^{0.2684} \\
& \{(14122.78-69.54 \times 15.72) / 0.7316\}^{0.7316}=15268.34
\end{aligned}
$$

The extra benefits obtained by households under the SOP are

$$
B_{s}=Y_{s 1}^{\prime}-Y_{s 1}=15268.34-14122.78=1145.56
$$

In the same way, the benefits for households under the ROP could be calculated as well. After renting public housing units, the per capita housing area is 12.21 square metres. Given 3.75 persons per household, the average housing area is 45.79 square metres $\left(H_{r 1}\right)$. The average market rent of housing per square metre is $87.6 \mathrm{RMB}\left(P_{H}^{e r}\right)$ (Shu 2012). The average rent for a public housing unit per square metre per year is $14.64 \operatorname{RMB}\left(P_{H_{1}}^{r}\right.$, shown in Table 2). The average annual disposable income for households under the ROP is $15858.5 \mathrm{RMB}$ ( $Y_{r 1}$, shown in Table 2). Therefore, the necessary income for households under the ROP is as follows:

$$
\begin{aligned}
& Y_{r 1}^{\prime}=(45.79 \times 87.6 / 0.0815)^{0.0815} \\
& \{(15868.5-45.79 \times 14.64) / 0.9185\}^{0.9185}=18073.68
\end{aligned}
$$

Based on Equation (9), the extra benefits of households under the ROP are

$$
B_{r}=Y_{r 1}^{\prime}-Y_{r 1}=18073.68-15858.5=2215.18
$$

From the outcomes shown in Equation (16) and (18), all households benefit from participating in the public housing programme. As $B_{r}>B_{s}$, the benefits obtained by households under the ROP are greater than those of households under the SOP.

As out study only uses data from two years, it is difficult to ascertain the benefits to these households in the long term. In addition, the sample is only from Baoji. Other cities may show different results. Thus, we conclude that the SOP in Baoji also brings households extra benefits in the short term. However, the ROP appears to be the more effective public housing programme. Therefore, the Baoji government should first adopt the ROP. The implementation of the SOP should be more careful.

\section{CONCLUSION}

This paper analyses the benefits and satisfaction of households who participated in the public housing programme in Baoji. To evaluate the effects of the SOP, this study divides the surveyed low-income households into two groups: households under the SOP and households under the ROP. We estimate the utility function for each group, based on which we calculate and compare the benefits of the households. Lastly, we summarize the level of households' satisfaction on the public housing programme. The main conclusions are as follows:

(1) Households joining under the SOP have a stronger taste in houses than households joining under the ROP. Using the survey data from Baoji, the $\alpha$ of households under the SOP is 0.2684 and that of households under the ROP is 0.0815 . These results reveal that households under the SOP value housing consumption more than those under the ROP. This is one important reason why the households under the SOP prefer to buy public housing units, even though their incomes are lower than households under the ROP.

(2) Both SOP and ROP offer benefits to the households participating in the public housing programme. However, the ROP brings greater benefits to low-income households than the SOP. After participating in the programme, households under the SOP obtain an extra benefit of 1145.56 RMB, while households under the ROP obtain $2215.18 \mathrm{RMB}$. As a result, the ROP appears to be more efficient than the SOP. When the local government of Baoji implements the public housing programme, they should first adopt the ROP, and control the units of public housing sold, as this is the less efficient policy. To achieve policy efficiency, restricting resale by the purchasers is the key point (Ho 1995).

That this study only had 75 households in our sample poses some limitations. In addition, the lack of data from other regions of China is another limitation. 
This research could be used as a foundation for further research into the effects of the SOP and ROP for the entire country. Another possible area for future research would be to explore the effects of the public housing programme from the point of view of society as a whole, rather than just low-income households.

\section{ACKNOWLEDGEMENTS}

The author is grateful to an anonymous referee, Professor Shigeyuki HAMORI (Kobe University), Professor Masahiko YOSHII (Kobe University), and Professor Keiko HIRONO (Nihon University), who provided important and useful suggestions. The author is also grateful to Professor Jin $\mathrm{YU}$, who provided advice during the first stage of the study. All remaining errors are the author's responsibility.

\section{REFERENCES}

CEIC Database. China Premium Database. Available at http://www.ceicdata.com (accessed 09 November, 2013).

Deng, L., Shen, Q., and Wang, L. 2009. "Housing Policy and Finance in China: A Literature Review." Paper prepared for U.S. Department of Housing and Urban Development, November 2009, America.

Flynn, R. 1988. "Political Acquiescence, Privatisation and Residualisation in British Housing Policy." Journal of Social Policy 17: 289-312. http://dx.doi.org/10.1017/S0047279400016822

Gilbert, A. 2004. "Helping the Poor through Housing Subsidies: Lessons from Chile, Colombia and South Africa." Habitat International 28: 13-40. http://dx.doi.org/10.1016/S0197-3975(02)00070-X

Gilbert, A. 2012. "Housing Subsidies in the Developing World." International Encyclopaedia of Housing and Home (Volume null) 638-643.

Ho, L.S. 1995. "Privatization of Public Housing: An Analysis of Policy Alternatives." Comparative Economic Policy 13: 53-63. http://dx.doi.org/10.1111/j.1465-7287.1995.tb00722.x

Ho, M.H.C. 2004. "Privatization of Public Housing in Hong Kong: A Genuine Agenda or Propaganda." Habitat International 28: 481-494.

http://dx.doi.org/10.1016/S0197-3975(03)00046-8
Jiang, L. 2007. "Research on the Rental Housing for Low-Income Households in Abroad (in Chinese)." Journal of Real Estate in Shanghai 11: 61-63.

Johnson, M.P. and Hurter, A.P. 2000. "Decision Support for a Housing Mobility Program Using a Multi-objective Optimization Model." Management Science 46: 1569-1584. http://dx.doi.org/10.1287/mnsc.46.12.1569.12077

Kirwan, R.M. 1984. "The Demise of Public Housing?" Pp. 133-145 in Privatisation and the Welfare State, edited by Le Grand J. and Robinson, R. London: George Allen and Unwin.

Koning, R.H. and Ridder, G. 1997. "Rent Assistance and Housing Demand." Journal of Public Economics 66: 1-31. http://dx.doi.org/10.1016/S0047-2727(97)00024-8

Kraft, J. and Olsen, O.E. 1977. "The Distribution of Benefits from Public Housing." Pp. 51-70 in Distribution of Economic WellBeing, edited by $F$. Thomas Juster. Cambridge: NBER.

Liu, Y. 2004. "Economic Effects on Housing Security Policy for Urban Poverty Groups (in Chinese)." Journal of Reform of Economic System 5: 45-48

Murray, M.P. 1975. "The Distribution of Tenant Benefits in Public Housing." Econometrica 43: 771-787. http://dx.doi.org/10.2307/1913085

Schill, M.H. 1990. "Privatizing Federal Low Income Housing Assistance: The Case of Public Housing." Cornell Law Review 75: 877-947.

Shu, P. 2012. "Rent Subsidies Increase since Next Year (Chinese News)," Baoji Express, December 6, Available at http://baoji.hsw.cn/system/2012/12/06/051551947.shtml (accessed 06 November, 2013).

Tiwari, P. and Hasegawa, H. 2001. "Welfare Effects of Public Housing in Tokyo." Journal of Policy Modeling 23: 421-431. http://dx.doi.org/10.1016/S0161-8938(01)00057-6

Wong, Y. and Liu, P. 1988. "The Distribution of Benefits among Public Housing Tenants in Hong Kong and Related Policy Issues." Journal of Urban Economics 23: 1-20. http://dx.doi.org/10.1016/0094-1190(88)90002-2

Xie, Y. 2011. "Research on the Land Scale Control Model of Public Housing Construction in China: An Example of Harbin." Prodedia Engineering 15: 5121-5215. http://dx.doi.org/10.1016/j.proeng.2011.08.950

Zhang, Y. 2009. "Analysis on Low-Rent Housing Subsidy (in Chinese)." Journal of Construction of Fujian 130: 77-79.

Zhou, L. 2008. "Performance Evaluation on Housing Allowance: Example from Shanghai (in Chinese)." China Reform 174: 68-72.

Zhou, L. 2010. "Consumption Attribution of Housing Subsidies and the Factors - Logistic Test Based on a Survey Data of the Low-income Rent Allowance Policy in Shanghai (in Chinese)." Journal of Shanghai Economic Review 4: 90-98.

\section{DOI: http://dx.doi.org/10.6000/1929-7092.2014.03.25}

(c) 2014 Nannan Yuan; Licensee Lifescience Global.

This is an open access article licensed under the terms of the Creative Commons Attribution Non-Commercial License (http://creativecommons.org/licenses/by-nc/3.0/) which permits unrestricted, non-commercial use, distribution and reproduction in any medium, provided the work is properly cited. 